\title{
O que os olhos não veem o corpo não veste: a moda impressa no Rio de Janeiro (1852-1855)
}

What the eyes do not see the body does not wear: the fashion printed in Rio de Janeiro (1852-1855)

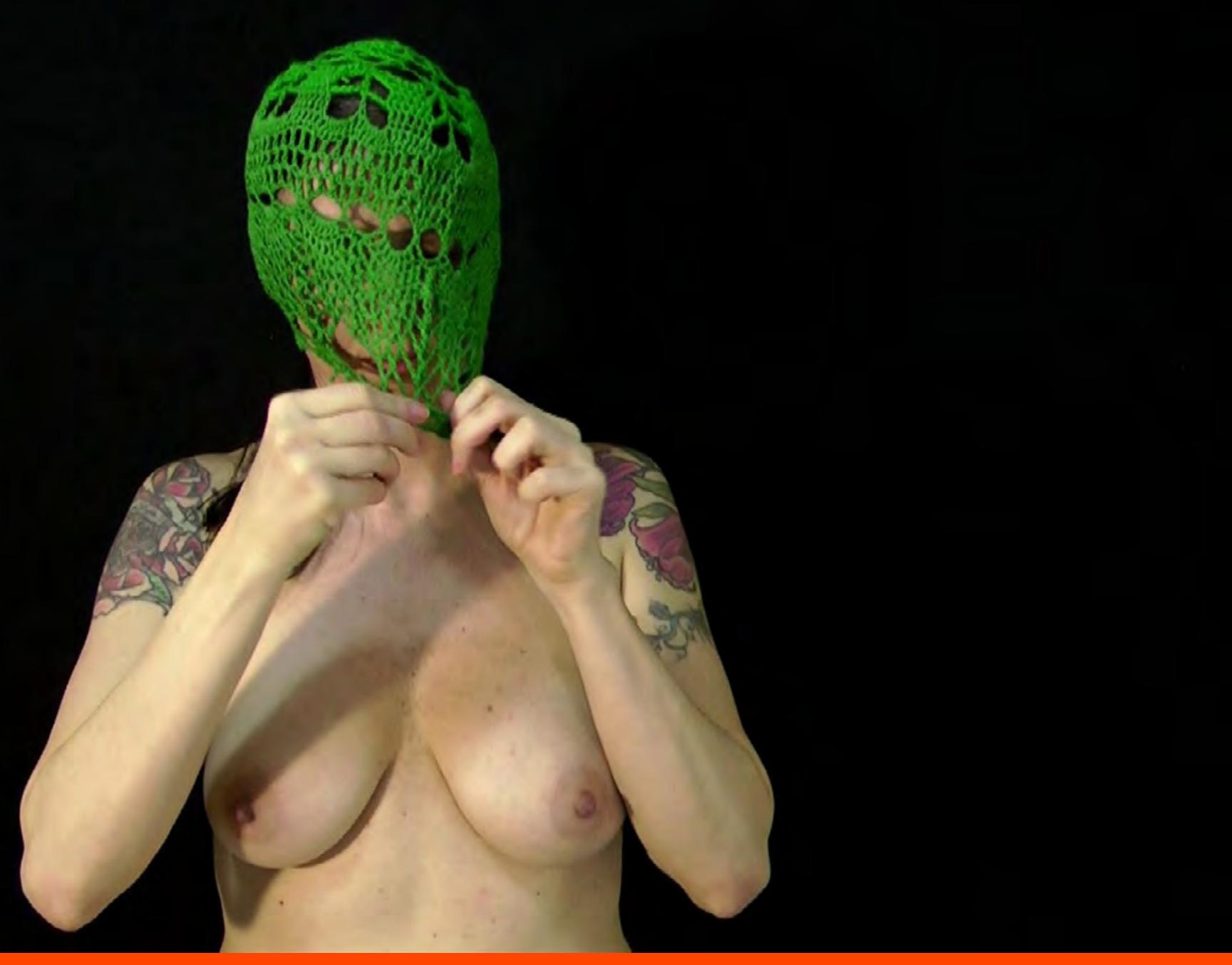




\section{Everton Vieira Barbosa ${ }^{1}$}

ORCID: https://orcid.org/0000-0003-2480-7397

[resumo] Na metade do século XIX o público feminino podia contemplar ilustrações de modas vindas da França, publicadas em periódicos estrangeiros, como o Le Moniteur de la Mode (1843-1913), e anexadas em publicações brasileiras, como O Jornal das Senhoras (1852-1855). Essas peças vinham acompanhadas de uma descrição, indicando os espaços e os horários recomendados para o uso daquela indumentária, assim como o tipo de tecido, as partes do vestuário, as cores, os formatos, os penteados e demais adereços que compunham a ilustração. A partir dessa relação entre texto e imagem, propomos analisar o papel social que as redatoras-chefes do 0 Jornal das Senhoras tiveram no processo de transferência e de mediação da cultura da moda parisiense, moldando os gostos e os hábitos de se vestir no Rio de Janeiro Oitocentista por meio dos textos traduzidos e das ilustrações de moda anexadas nesse impresso.

\section{[palavras-chave] Moda impressa. Mulheres. O Jornal das Senhoras.}

[abstract] In the middle of the 19th century, the female public could contemplate French fashion illustrations published in journals such as Le Moniteur de la Mode (1843-1913), annexed in Brazilian publications, such as O Jornal das Senhoras (1852-1855). These pieces were accompanied by a description that indicated the time and places recommended to use those garments, as well as the type of fabric, parts of the clothing, colors, shapes, hairstyles and other props that comprised the illustration. Based on this relationship between text and image, we propose an analysis of the social role that the editor-in-chief of O Jornal das Senhoras played in the process of transference and mediation of the Parisian fashion culture, shaping the tastes and habits of dress in the nineteenth-century Rio de Janeiro through the translated texts and fashion illustrations attached to this print.

[keywords] Fashion printed. Women. O Jornal das Senhoras.

Recebido em: 24-01-2019

Aprovado em: 04-07-2019 ${ }^{1}$ Doutorando em História pela Universidade Federal Fluminense. Mestre em História pela Unesp (Assis).
Bolsista Capes. E-mail: semusico@hotmail.com. Lattes: http://lattes.cnpq.br/3719090115264390. 


\section{Introdução}

O provérbio popular "o que os olhos não veem o coração não sente" comumente pode ser atribuído a distintas questões que envolvem o gosto de alguém sobre determinado objeto, alimento, pessoa ou situação desconhecida.

O relato de uma escritora para O Jornal das Senhoras (1852-1855) sobre a Folia de Reis exemplifica um dos sentidos dados à frase. Em sua descrição, ela "julgava que isto de cantar os reis, era um passeio romântico, em que com passo mesurado se gozava do belo luar, da música, do golpe de vista sem igual da nossa baia" (O JORNAL DAS SENHORAS, n. 3, 18 jan. 1852, p. 3-4).

Ainda sem ter total noção do divertimento, a escritora idealizou uma situação romântica tal qual já conhecia e gostava. Porém, quando cruzou a Baía de Guanabara, do Rio de Janeiro a Niterói para vivenciar a festividade, ela se deparou com o entra e sai de pessoas nas residências e seu deslocamento pela cidade cantando e tocando músicas típicas, mudando toda a ideia que havia feito da Folia de Reis.

A desconstrução da ideia projetada sobre a festividade pela escritora não impediu que ela compreendesse o real sentido do evento e experimentasse a nova situação de forma proveitosa. Ao fim da festa, ela relatou que "salvo o passo de carga, a poeira que cegavam e as informações falsas e outros inconvenientes, que eu cá sei, deve continuar o uso da cantata de Reis. Se para o ano aqui estiver não faltarei a ela" (O JORNAL DAS SENHORAS, n. 3, 18 jan. 1852 , p. 4, grifo do autor), indicando ter gostado de participar daquele divertimento que antes lhe era desconhecido.

Com isso, podemos perceber que as "informações falsas" recebidas pela escritora foi um dos motivos que a influenciaram na construção de uma ideia romantizada da Folia de Reis. Somente depois de ter visto e vivido a festividade que ela realmente pôde sentir e entender como era participar do evento.

Mas o relato acima foi um dos muitos exemplos extraídos do O Jornal das Senhoras associado ao provérbio popular "o que os olhos não veem o coração não sente". Tal relação pode ser identificada e comprovada nos processos de expectativa e frustração que são projetados por cada indivíduo ou grupo perante determinadas situações e ações no tempo e no espaço histórico.

Como exemplo, ao descrever as apresentações teatrais e musicais assistidas naquela semana, a redatora-chefe do O Jornal das Senhoras, Joanna Paula Manso de Noronha (19191975), relatou a frustração que teve com alguns cantores franceses:

Estavam anunciados para esta noite uns cantores franceses de passagem para a Califórnia. Ah! E lá foram; e lá se apresentaram!

Eles dizem que vem de Paris, o que importa dizer que este só - venho de Paris - é uma recomendação. - Uma pessoa que vem de Paris por força tem algum merecimento; pois d'esta vez Paris fez fiasco. - 
Santos Céus! A república terá feito uma tal revolução nas artes que deveras esses sujeitos seriam por lá cantores, pianistas ou quer que seja?! Malvestidos, com cada mão, como de quem se criou a cavar com a enxada; e sobretudo que execução de pianista, que porte de Barítono em cena!!! Que Dama!!! (O JORNAL DAS SENHORAS, n. 3, 18 jan. 1852, p. 8)

É possível perceber que a insatisfação da redatora foi motivada pelo fato de os cantores franceses não corresponderem às suas expectativas. 0 prestígio e o merecimento dados aos artistas europeus, e nesse caso aos cantores franceses, eram comuns para a época, uma vez que o Brasil se espelhava nos costumes e nas manifestações artísticas do Velho Continente para moldar sua identidade cultural, ainda em construção (BOTREL, 2012).

Diferentemente da escritora que participou e gostou da Folia de Reis, a redatora Joanna Paula Manso de Noronha não aprovou a apresentação dos cantores franceses, sendo contundente em sua crítica a eles e ao público presente:

E houveram palmas!!!

Queremos supor que foram de caçoada; porque o público do Rio de Janeiro não pode ter esquecido o que são concertos, e a escolhida polidez dos artistas nesses soirées do bom-tom, que muito desejaríamos não caíssem em desuso em uma Corte onde já é sensível a falta de um salão de concertos. (O JORNAL DAS SENHORAS, n. 3, 18 jan. 1852, p. 8)

Nesse sentido, as palmas podiam servir como termômetro para identificar se determinado evento agradou ou não ao público espectador. Já a desconstrução da ideia de que vindas da Europa, em especial da França, todas as manifestações artísticas são recomendadas e podem ser assistidas pelo seleto público da Corte brasileira confirma o provérbio popular "o que os olhos não veem o coração não sente".

Afinal, era sabida a reputação europeia dos grandes e suntuosos espetáculos artísticos que agradavam a toda gente, a ponto de serem recomendados até de olhos fechados. Porém, a péssima performance musical, assim como as vestimentas de mau gosto utilizadas pelos cantores franceses foram entendidas pela redatora como falta de polidez e de bom-tom.

Ainda sobre esse relato, a menção de Joanna sobre as más roupas dos intérpretes chama a atenção pelo fato de a França ser considerada exemplo e símbolo da moda para o mundo, como fora tratado por vasta literatura (MILLET, 2020; CARELLI, 1993; RAINHO, 2002; MONTELEONE, 2013).

A representatividade da cultura francesa entre as brasileiras já era conhecida, pois "no Brasil as ideias 'afrancesadas' chega[va]m com os alunos que estudavam fora da colônia" (HILSDORF, 2005, p. 29, acréscimo nosso), com os livros clandestinos, os periódicos, as sociedades letradas, os professores e também pelas ações da Corte joanina, demonstrando as diferenças existentes no processo de transferência e de mediação desse fenômeno em determinados tempos e espaços. 
No caso específico da imprensa, devemos levar em conta seu papel como propagadora e divulgadora de textos e, posteriormente, de imagens sobre a cultura e a moda francesas. Esses materiais, ao circularem pelo país, instruíam as leitoras interessadas em se vestir e se portar conforme as recomendações impressas.

É nesse sentido que temos a intenção de analisar o papel social das redatoras-chefes do 0 Jornal das Senhoras no processo de transferência e de mediação da cultura da moda francesa, moldando os gostos e os hábitos de se vestir no Rio de Janeiro Oitocentista, relacionando o provérbio popular "o que os olhos não veem o coração não sente" ao aspecto da aparência.

Essa associação pode ser feita na medida em que as leitoras das revistas com conteúdo de moda precisavam ler e ver os modelos publicados a fim de se vestirem publicamente conforme o que era estabelecido nos periódicos. Tal procedimento era seguido pelas mulheres que, ao buscar parecerem belas, elegantes, modernas e com bom-tom, tinham a intenção de serem incluídas ou permanecerem em um seleto grupo socioeconômico nos quais a cultura e a moda francesas imperavam.

\section{Os primeiros periódicos com conteúdo de moda no Brasil}

No Brasil, os primeiros impressos que publicaram informações sobre moda surgiram "em decorrência de uma oportunidade de negócios e de uma demanda local por periódicos em língua portuguesa dirigidos especificamente a mulheres” (SILVA, 2018, p. 47). Como exemplo, podemos destacar $O$ Espelho Diamantino (1827-1828), publicado na capital do Império pelo redator Julio Floro das Palmeiras. Na sua terceira edição, o periódico já afirmava que no Rio de Janeiro “a moda vem da França” (O ESPELHO DIAMANTINO, n. 3, 15 out. 1827, p. 13).

Dois anos depois, em 1829, na primeira edição do jornal O Mentor das Brasileiras (1829-1832), publicado na cidade de São João del Rey, o redator José Alcibíades Carneiro escreveu que "neste País a moda, vem da França" (O MENTOR DAS BRASILEIRAS, n. 1, 7 dez. 1829, p. 7), atestando a importância da moda francesa no Brasil.

Já em outros periódicos veiculados no Brasil, mesmo que não houvesse artigos específicos sobre o assunto, seus redatores-chefes publicavam informações sobre a moda de diferentes maneiras. No Jornal do Commercio eram comuns os anúncios de diversos tipos de objetos e vestimentas de origem francesa vendidos na Rua do Ouvidor e em outras ruas centrais do Rio de Janeiro. E entre os anos 1844 e 1889, o impresso Almanak Administrativo, Mercantil e Industrial do Rio de Janeiro, dos irmãos franceses Eduardo e Henrique Laemmert, divulgou várias propagandas sobre o ensino da língua francesa, os estabelecimentos comerciais e/ou voltados à venda de produtos de Paris, assim como o nome de comerciantes e demais agentes históricos provindos da França e estabelecidos no Rio de Janeiro (MENEZES, 2004).

Diante de todas essas informações, era difícil para a redatora-chefe Joanna Paula Manso de Noronha e para tantos outros brasileiros imaginar que um espetáculo apresentado por cantores de origem francesa pudesse ser um fiasco, como fora relatado por ela no periódico 0 Jornal das Senhoras. Afinal, se ela não tivesse visto a exibição, possivelmente teria conservado a ideia geral da França como modelo de civilidade, de modernidade, de bons 
costumes e de moda (SILVA, 2017). Por esse motivo, assistir a atuação com péssimo desempenho musical dos cantores estrangeiros, e ainda malvestidos, foi considerado um absurdo.

Assim, podemos considerar que o provérbio popular "o que os olhos não veem o coração não sente" não se aplicava a todas as situações vivenciadas e descritas em O Jornal das Senhoras.

Tanto no exemplo da Folia de Reis quanto no da apresentação feita pelos cantores do país hexagonal, compreendemos que se esses eventos não tivessem sido vistos e vividos pelas mulheres que relataram suas experiências, provavelmente elas conservariam uma ideia diferente daquela descrita no periódico feminino.

Essa associação também equivale à moda, pois se esse sistema (BARTHES, 1979) não fosse assimilado pelas mulheres que leem as revistas com conteúdo de moda, e se não estivessem preocupadas com suas aparências, certamente elas não dariam importância ao tipo de vestimenta usada socialmente.

Por isso, o título "o que os olhos não veem o corpo não veste" evidencia a importância do olhar feminino para a escolha e a avaliação dos trajes impressos que deveriam ser utilizados em determinados momentos e locais e a possibilidade de aprovação social que eles poderiam propiciar.

Dentre os periódicos femininos que publicavam conteúdos textuais e imagéticos sobre moda, podemos concentrar a nossa atenção em $O$ Jornal das Senhoras por ele ser organizado por mulheres. Durante os quatro anos de publicação desse impresso, as redatoras-chefes Joanna Paula Manso de Noronha (1819-1875), Violante Atabalipa Ximenes de Bivar e Vellasco (1817-1875) e Gervasia Nunezia Pires dos Santos Neves (1824-1872) tiveram a preocupação de manter suas leitoras constantemente informadas e atualizadas sobre o universo da moda.

Joanna Paula Manso de Noronha era uma argentina exilada no Brasil desde a década de 1840 por causa de sua oposição à conjuntura política de seu país. No Brasil, ela iniciou a publicação do 0 Jornal das Senhoras com o propósito de reivindicar a equiparação educacional entre homens e mulheres. Além disso, seus artigos expunham a submissão feminina diante de uma sociedade patriarcal, propondo reflexões sobre a igualdade civil entre os sexos e o melhoramento social feminino por meio da educação (BARBOSA, 2018).

Após seis meses na direção do periódico, Joanna Paula Manso de Noronha retorna à Argentina, por causa das mudanças políticas em seu país, passando o cargo para Violante Atabalipa Ximenes de Bivar e Vellasco, que, na época, era colaboradora da seção das modas.

Ao assumir a direção do O Jornal das Senhoras, Violante manteve a publicação de alguns artigos sobre a equiparação educacional entre os sexos, assim como outros textos que retratavam a condição feminina no Brasil naquela época. Depois de 11 meses no comando do jornal, Violante passa o cargo para a colaboradora Gervasia Nunezia Pires dos Santos Neves sem justificar sua saída às assinantes do O Jornal das Senhoras.

A terceira redatora, Gervasia, permanece dois anos e sete meses à frente da publicação, mantendo com menor frequência os artigos sobre a condição feminina. De modo mais conservador que suas antecessoras, Gervasia utilizava os romances e os artigos religiosos e de cunho moral a fim de expor a submissão da mulher e propor uma valorização do seu papel no espaço doméstico com os filhos e o marido. 
Ao observarmos que as principais pautas para essas mulheres eram a educação igualitária entre os sexos e um tratamento mais adequado como mãe e esposa, podemos compreender que 0 Jornal das Senhoras "foi o objeto político, utilizado como instrumento de instrução, de diálogo e de poder para dar voz, visibilidade e legitimidade ao discurso feminino" (BARBOSA, 2018, p. 115-116).

Os assuntos sobre moda inseridos no periódico vinham ao encontro do interesse feminino naquele momento, pois ao mesmo tempo que os artigos possuíam um sentido pedagógico, ao instruir suas assinantes sobre o uso de determinada vestimenta em espaços e lugares vivenciados no cotidiano brasileiro, os textos e as ilustrações representavam a construção do olhar e do gosto sobre um estilo de ser e agir socialmente. Na inserção dessas informações, as redatoras do periódico feminino empregavam diversas estratégias editoriais a fim de proporcionar às suas assinantes conteúdos atualizados sobre moda, figurinos e demais adereços utilizados no corpo.

Um dos recursos usados foi a anexação de ilustrações litografadas extraídas de periódicos franceses. Das 166 imagens de moda inseridas em OJornal das Senhoras, consultamos aproximadamente cem delas para analisar a diversidade de vestimentas e suas respectivas descrições textuais com a finalidade de identificar as instruções sobre os espaços adequados para a utilização daquela indumentária.

A mediação cultural realizada pelas redatoras-chefes do jornal configurava-se em uma verdadeira trama cultural, envolvendo acordos com redatores e comerciantes de outros países e a circulação de seus impressos e produtos de moda pelo Atlântico por meio de embarcações marítimas.

A movimentação desses objetos culturais da Europa para o Brasil e a sua anexação no periódico feminino atestam as redes de negociação dessas mulheres não apenas com redatores, mas com modistas, alfaiates, cabeleireiros, costureiras e demais agentes históricos vinculados direta ou indiretamente ao universo da moda.

A importação de tecidos, roupas prontas e diversos acessórios corporais abrangia mais de 70\% de tudo o que era comercializado entre o Brasil e a Inglaterra (MONTELEONE, 2013).

Ainda que cada membro dessa rede de negociações possuísse objetivos específicos, foi a relação entre esses indivíduos que possibilitou a transferência, a mediação e a propagação do que havia de mais moderno no Velho Continente.

Tal divulgação se enquadrava nos objetivos das redatoras do 0 Jornal das Senhoras. Cientes do interesse feminino pela moda parisiense, a constante inserção das ilustrações de moda e suas respectivas descrições no periódico angariava novas assinantes.

Entretanto, deve-se frisar que $O$ Jornal das Senhoras não foi a primeira publicação brasileira a inserir ilustrações de modas em suas páginas. Antes dele, impressos como $O$ Correio das Modas (1839-1840) e Marmota na Corte (1849-1852) já anexavam croquis de vestidos extraídos de periódicos franceses. No Correio das Modas, as imagens com representações da moda feminina foram desenhadas pela artista Adele-Annaïs Colin Toudouze (1822-1899) e tiradas do jornal Le Follet (1829-1882). Já os trajes masculinos foram feitos pelo artista Damours (DONEGA, 2014) e reproduzidos do Modes de Paris: Journal de Tailleurs (1830-1896). 
Essa diversidade de publicações vindas da França e suas respectivas estampas evidencia a circulação de impressos estrangeiros no Rio de Janeiro ao longo do século XIX (GUIMARÃES, 2016, 2018). Entre os de origem francesa que serviram de inspiração para a elaboração dos artigos sobre moda no Marmota na Corte, o redator Francisco de Paula Brito menciona "o Follet, Bon Ton, Petit Courier, Favori des Dames, e o Caprice" (MARMOTA NA CORTE, n. 151, 22 abr. 1851, p. 1, grifo do autor), enquanto que no O Jornal das Senhoras encontramos referências ao Le Follet (1829-1882), Petit Courrier de Dames (1821-1868), Les Modes Parisiennes (1844-1885) e Moniteur de la Mode (1843-1913) (BARBOSA, 2018).

Ao desembarcar no porto, tais periódicos e litografias eram enviados aos estabelecimentos comerciais dos distintos mediadores culturais existentes na cidade. Em seguida, eles chegavam às mãos das redatoras que circulavam pelas ruas e lojas de modistas, alfaiates e demais costureiras a fim de fazer consultas e obter pareceres sobre as informações recebidas da Europa, para então realizarem a tradução e a descrição da ilustração que seria impressa na próxima edição do periódico.

Ao justificar para as assinantes do 0 Jornal das Senhoras o atraso na chegada dos figurinos de Paris e a respectiva falta da descrição da estampa na 46 a edição, publicada em 14 de novembro de 1852, a escritora de pseudônimo Christina relata sua rotina de trabalho:

Eu a humílima redatora das modas, que tenho de ler jornais, consultar a inteligente interpretação de Mme. Barat, ir ao armazém de Wallerstein, conversar com Mme. Hortence Laccarrière, visitar Mme. Josephine, enfim preparar-me, orientar-me em forma de vos poder escrever conscienciosamente [...] em menos de uma hora, que foi todo o tempo marcado pela tal impaciente ordenança?! (0 JORNAL DAS SENHORAS, n. 46, 14 nov. 1852, p. 8)

Nessa descrição, é possível perceber parte do processo de mediação cultural realizado por Christina. Assim que os jornais franceses chegavam aos estabelecimentos comerciais, ela era encarregada de buscá-los nas distintas lojas de modistas, cabeleireiros e demais comerciantes. Depois disso, eram necessárias uma leitura prévia do impresso e uma análise da ilustração para só então circular novamente pelos comércios a fim de obter maiores informações sobre os tecidos, as cores, os adereços e as peças à venda.

Saber da disponibilidade dos tecidos e adereços que compunham a ilustração era necessário e fundamental às escritoras no processo de tradução e transcrição da estampa para o periódico. Afinal, era nessa descrição que as assinantes se pautavam para buscar, nos estabelecimentos comerciais, tecidos e aviamentos para que pudessem confeccionar vestimentas semelhantes às vistas nos jornais, com as adaptações necessárias.

Por isso, o processo de tradução e transcrição textual contava com o recurso do ato editorial (OUVRY-VIAL, 2007). Essa estratégia visava estruturar o texto de acordo com as expectativas da leitora, na medida em que era adequado à realidade brasileira. A adaptação era realizada por causa da falta de algum elemento mostrado na ilustração ou mesmo pela diferença climática entre França e Brasil, influenciando a mudança de tecidos usados na composição dos vestidos.

Sem deixar de manter a base textual sobre as informações retiradas dos periódicos franceses, a inserção de assuntos considerados necessários ao seu público visava, com o ato 
editorial, tornar 0 Jornal das Senhoras uma publicação de leitura fácil e rápida, uma vez que não era comum às mulheres brasileiras, se comparadas às francesas, ler jornais exclusivos sobre moda.

Ao compreender que as francesas estavam tão habituadas a ler periódicos de moda, a autora do artigo de moda chega a supor que o Moniteur de la Mode tinha "uns cento e sessenta mil assinantes" (O JORNAL DAS SENHORAS, n. 36, 26 set. 1852, p. 1). Ainda que a quantidade mencionada não estivesse totalmente correta, tal suposição leva a compreender o espanto da redatora Joanna de Paula Manso de Noronha com a apresentação dos franceses malvestidos. Afinal, se a moda no Brasil era ditada pela França, e os intérpretes estavam acostumados com a imprensa de moda e a se vestir de acordo com o bom-tom, qualquer brasileira estranharia ver um francês mal trajado.

Essa noção permite compreender a importância da imprensa e das ilustrações como difusores de normas e condutas sociais. Ao determinar o que era adequado vestir em cada horário do dia e em cada espaço de sociabilidade, a descrição da estampa servia como um instrutor social, ditando aquilo que era caracterizado pelo bom-tom, pela elegância e pela modernidade.

0 ato de ler os textos em consonância com as imagens é elemento da pedagogia do olhar, compreendida pela formação de um saber se vestir e se portar socialmente. Esse conhecimento era iniciado na teoria impressa nos periódicos por meio das informações sobre a moda parisiense e completado, na prática, ao se vestir as indumentárias descritas nas estampas e usadas conforme as instruções textuais.

Se por um lado era possível e admissível ser surpreendida por um divertimento desconhecido, como a Folia de Reis, o mesmo não podia ocorrer com o universo da moda, especialmente se os artistas fossem franceses. Por esse motivo, era necessário saber ver e ler as informações textuais e imagéticas para poder se vestir e sair em público conforme a moda vigente.

\section{Ver e ler para vestir e sair}

A visualização e a leitura de imagens e textos sobre a moda exerciam um forte papel na formação da opinião pública, em especial das mulheres. Para além dos artigos de moda, as crônicas semanais, quinzenais, mensais, dos teatros, dos salões e musicais descreviam todo o cotidiano do Rio de Janeiro, incluindo os partícipes e seus trajes.

Em uma das crônicas dos salões, a escritora de pseudônimo Estrella relatou as músicas executadas na reunião mensal dada pela sociedade Phileuterpe e não deixou de mencionar os trajes vestidos no evento:

Vimos então voltear no salão duas moças, que se me não engano, são parentes; a simplicidade do seu toilette e a sua encantadora elegância, ainda uma vez nos fizeram crer, que a beleza não se deve sobrecarregar de muitos enfeites, para sempre dominar a atenção e as simpatias. Assim também admiramos muitas outras senhoras, cujo trajar estava a par do bom gosto. (O JORNAL DAS SENHORAS, n. 13, 28 mar. 1852, p. 3) 
Estar a par do que era considerado de bom gosto era essencial aos frequentadores desses espaços de sociabilidade uma vez que nada escapava aos olhares atentos dos colunistas dos periódicos. 0 redator Francisco de Paula Brito também aproveitava os divertimentos sociais para escrever sobre os figurinos usados pelos espectadores: na "sexta-feira da semana passada, assistindo à representação do drama Gabrina... no teatro de S. Francisco, notamos três toilettes de tanto gosto, que para logo não resistimos ao desejo de descrevê-los" (MARMOTA NA CORTE, n. 157, 13 maio 1851, p. 1, grifo do autor).

Da mesma forma que os redatores elogiavam todas as pessoas que estavam bem trajadas, eles não mediam esforços para criticar quem destoasse do padrão da moda. Por esse motivo, estar atento e se vestir de acordo com os costumes vigentes não eram necessariamente um aspecto de frivolidade e ostentação social, mas denotavam polidez, elegância e conhecimento associados à ideia de modernidade e vinculados ao prestígio social.

Assim como as cartilhas de bom-tom padronizavam as boas maneiras de agir socialmente, as estampas ilustradas com os vestidos usados em Paris e suas descrições serviam como referencial normativo para homens e mulheres que buscavam se enquadrar no mundo da moda.

No caso do O Jornal das Senhoras, o Moniteur de la Mode serviu como exemplo para as redatoras Joanna, Violante e Gervasia na extração e na anexação de litografias com imagens de vestidos, adereços e pontos de bordados, além das descrições das estampas que eram traduzidas, copiadas e inseridas no artigo de moda do periódico brasileiro.

Um dos aspectos de relevância para a leitura e a adesão das assinaturas do jornal era o caráter de ineditismo que as imagens traziam. Três meses era o período aproximado que as embarcações comerciais levavam entre a França e o Brasil. E esse era o tempo médio que as ilustrações do Moniteur de la Mode demoravam para chegar ao Rio de Janeiro e atualizar as leitoras brasileiras, aproximando dois continentes, dois países, dois modos de vida distintos.

Ao analisar a procedência, a circulação e a apropriação das estampas inseridas no periódico A Illustração (1884-1892), Tania Regina de Luca constatou um patente compromisso do redator com a atualidade. Esse acordo deveu-se à extração de textos e imagens de outras publicações "que eram arranjados num todo particular a cada edição, o que evoca a ideia de um mosaico, composto ao sabor das circunstâncias" (LUCA, 2018, p. 180).

Tais arranjos e mosaicos também foram comuns em 0 Jornal das Senhoras, seja na inserção de poemas, poesias, romances, contos e demais textos extraídos e traduzidos de outros jornais, seja na tradução, na adaptação, na descrição e na anexação das ilustrações francesas.

Com o intuito de manter a originalidade na descrição das imagens copiadas do periódico francês, a redatora do O Jornal das Senhoras escreveu para as suas assinantes, no artigo de moda, que manteria as intenções do pintor das litografias, mas sem deixar de expor sua opinião quando discordasse de algo:

Hei de apresenta-vos sempre os nossos figurinos tais quais eles são interpretados tal qual foi a intenção de Jules David ao desenhá-los guiado pelas amestradas explicações das primeiras e mais notáveis artistas da grande capital do mundo 
elegante. E também francamente vos direi a minha opinião quando o excesso de qualquer moda me não agradar. (O JORNAL DAS SENHORAS, n. 54, 9 jan. 1853, p. 2, grifos do autor)

Pintadas pelo artista Jean-Baptiste David (1808-1892), conhecido como Jules David, as litografias impressas no Moniteur de la Mode retratavam o cotidiano feminino francês no transcorrer do século XIX.

\begin{abstract}
Em meados da década de 1830 a maioria das placas representava duas mulheres, na esfera doméstica ou ao ar livre, envolvidas em atividades femininas de classe alta ou média, tais como participar de bailes - incluindo o baile a fantasia para crianças - recebendo uma visita no salão, tocando pianoforte, lendo livros ou revistas, escrevendo ou lendo cartas, fazendo bordado, esboçando, pintando, e passeando nos jardins, parques ou pelas propriedades rurais. (HAHN, 2009, p. 67-68)
\end{abstract}

Os diversos espaços e vestidos retratados nas litografias francesas serviam de inspiração às leitoras brasileiras que viam nas imagens um ar de novidade e modernidade daquilo que era vivido e usado na Europa naquele momento.

Tania Regina de Luca menciona que as ilustrações internacionais que circulavam nos periódicos brasileiros no século XIX possuem grande importância "na formação do olhar e na difusão de valores, hábitos, comportamentos, assim como de projetos estéticos" (LUCA, 2017, de 1:18:24 a 1:18:30). A formação do olhar era feita por uma pedagogia das imagens e pela descrição das estampas do Moniteur de la Mode, que eram traduzidas e inseridas no artigo sobre moda do $O$ Jornal das Senhoras.

Ainda que as cópias feitas para 0 Jornal das Senhoras fossem a preto e branco, dado o custo da impressão colorida, a descrição das ilustrações indicava as cores das vestimentas, assim como instruía suas leitoras quanto aos determinados espaços e momentos que aquela roupa deveria ser usada.

Diante da vasta gama de periódicos franceses sobre moda que já circulavam pela cidade do Rio de Janeiro, a escolha da redatora Joanna Paula Manso de Noronha em estabelecer um acordo comercial com o redator do Moniteur de la Mode, Camille Adolphe Goubaud, possivelmente deve ter sido feita sob a mediação dos comerciantes Alexandre e Francisco Demarais.

Esses franceses, donos de um estabelecimento comercial voltado ao embelezamento feminino situado na Rua do Ouvidor, número 86, recebiam o Moniteur de la Mode desde 1845, indicando que o impresso já circulava pelo Brasil há alguns anos, antes do lançamento de 0 Jornal das Senhoras.

Em seu primeiro ano de publicação, em 1843, o Moniteur de la Mode circulava pela Suíça, Itália, Bélgica, Holanda, Inglaterra, Alemanha e pelos Estados Unidos da América, exportando os costumes e os modos de vestir da sociedade francesa.

Desde o lançamento do O Jornal das Senhoras, em 1852, os comerciantes Alexandre e Francisco Demarais revendiam o impresso estrangeiro para Joana, Violante e Gervasia, intermediando o contato entre as redatoras brasileiras com o periódico francês. 
Para além de 0 Jornal das Senhoras, as ilustrações de moda do Moniteur de la Mode também foram utilizadas em $O$ Espelho (1859-1860), demonstrando sua importância como difusor da moda francesa no Brasil (O ESPELHO, n. 3, 18 set. 1859, p. 9).

A parceria firmada entre os redatores do Moniteur de la Mode e do O Jornal das Senhoras pode ser identificada na descrição feita por Violante Atabalipa Ximenes de Bivar e Vellasco, que contestava alguns críticos do periódico feminino sobre a originalidade das imagens francesas inseridas no impresso brasileiro:

Desde que a Redação do JORNAL DAS SENHORAS foi autorizada para poder publicar regularmente os figurinos do Moniteur de la Mode que os deve apresentar às suas assinantes tais quais chegam eles de Paris.

O Moniteur de la Mode, querida leitora, é sem dúvida o primeiro dos mais bem conceituados JORNAIS de modas de Paris, e suas delicadíssimas Estampas o comprovam. Não podendo, portanto, o JORNAL DAS SENHORAS apresentar por ora modas inventadas no seu país e querendo apresentar aquelas que mais felizmente são criadas em terra estranha, apoiou-se na primazia do Moniteur de la Mode, e publica no Rio de Janeiro as gravuras deste Jornal. (O JORNAL DAS SENHORAS, n. 65, 27 mar. 1853, p. 2, grifos do autor)

Com o acordo estabelecido, a cada três edições do mês, uma estampa com figurinos, pontos de bordados ou moldes de determinadas peças era publicada e descrita em $O$ Jornal das Senhoras. Na quarta edição do mês, era veiculada uma peça de partitura, contribuindo para o aprendizado musical das leitoras.

Sob o discurso de melhoramento social e emancipação moral da mulher, também eram publicados em 0 Jornal das Senhoras artigos voltados à ampliação dos conhecimentos femininos e ao acesso a determinadas atividades e trabalhos no espaço público. Dessa forma, a constante presença da moda nesse período não pode ser encarada como um assunto supérfluo ou de futilidades para a pesquisa histórica, mas ela indica a construção de representações femininas, apontando o modo como essas mulheres eram vistas e se viam naquela época, forjando os papéis de gênero construídos socialmente.

Tomando duas das muitas litografias publicadas no Moniteur de la Mode e copiadas em O Jornal das Senhoras, podemos observar a importância da descrição das estampas para instruir suas leitoras quanto à cor, tamanhos, penteados, adereços e espaços de sociabilidade nos quais as vestimentas ilustradas deveriam ser utilizadas.

A figura 1, publicada no Moniteur de la Mode em abril de 1852, e a figura 2, divulgada em 0 Jornal das Senhoras em agosto de 1852, representam duas senhoras com vestidos de baile. A descrição das cores do vestido, do tipo do tecido, dos comprimentos utilizados, dos penteados e dos demais adereços que ornam o conjunto da peça instruía as leitoras dos dois periódicos, ditando a moda que predominava naquele momento. 

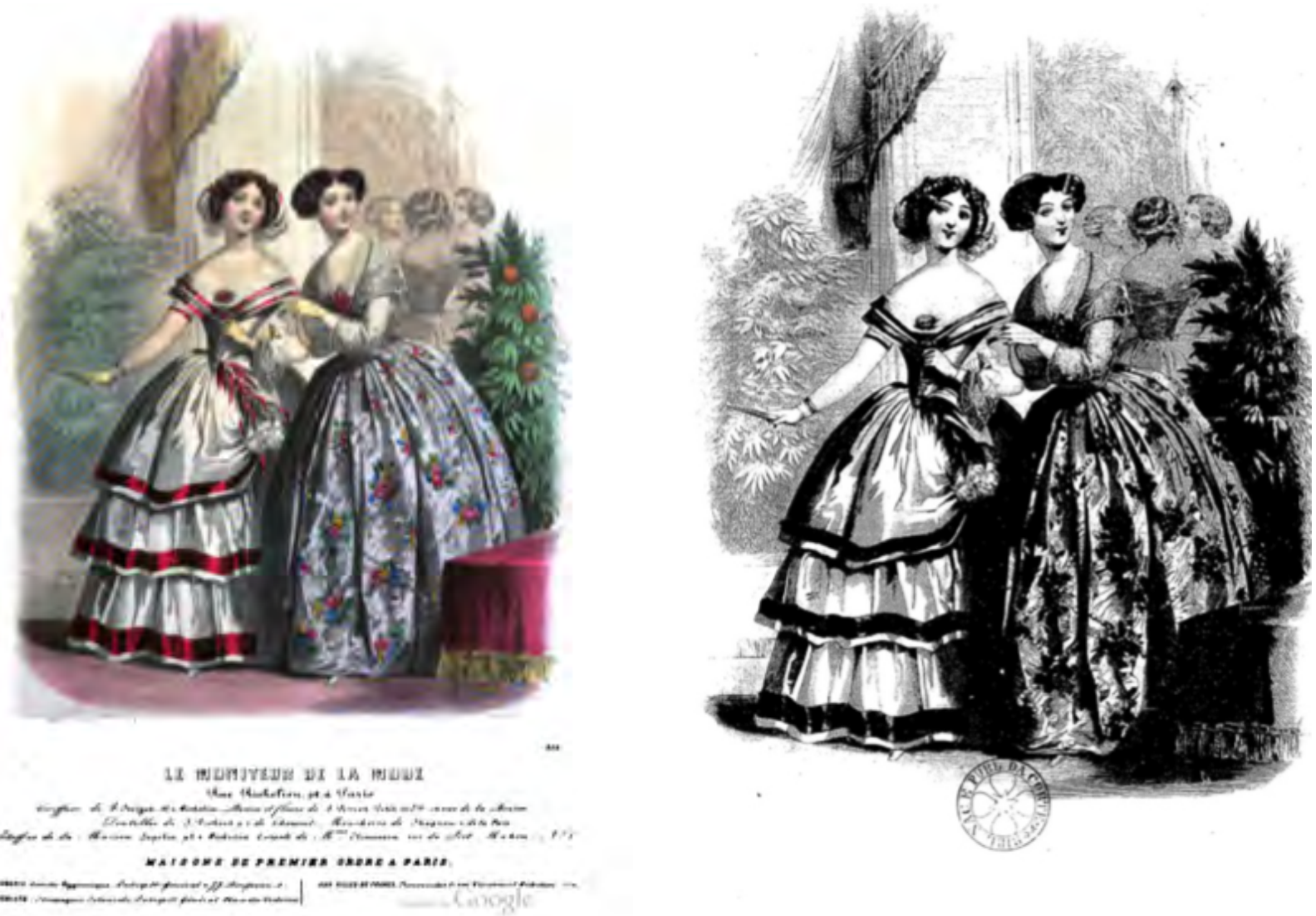

FONTE: Le Moniteur de la Mode. Paris: Imprimerie de E. Martinet, n. 4, abr. 1852, p. 65. Imagem obtida mediante impressão de tela do documento (figura 1). O Jornal das Senhoras. Rio de Janeiro: Tipografia do Jornal das Senhoras, n. 31, 1 ago.1852, p. 7. Imagem obtida mediante impressão de tela do documento (figura 2).

As estampas dos vestidos femininos destacavam-se pelas cores, pelos tamanhos e pelos adereços que completavam o traje ilustrado. A descrição textual da ilustração cumpria seu papel de traduzir todo o simbolismo retratado na imagem.

Sob o ato editorial da transcrição, é possível identificarmos algumas adaptações textuais do conteúdo original em francês na sua tradução em português.

No texto em francês, o penteado da dama retratada à esquerda da imagem é descrito com uma guirlanda de folhagens de juncos de veludo e ouro (LE MONITEUR DE LA MODE, $\mathrm{n}$. 4, abr. 1852, p. 56), o que se mantém na tradução brasileira sob o nome de "enfeite" vindo de Paris, composto por canudos de veludo trançados com um estreito galão de ouro (O JORNAL DAS SENHORAS, n. 31, 1 ago. 1852, p. 2).

Já a respeito do vestido da senhora à esquerda da imagem nas figuras 1 e 2 , na descrição francesa é indicado um modelo de tafetá enfeitado com veludo, dado seu comprimento em centímetros. Na tradução em português, o mesmo vestido é de escumilha, com saias progressivas em tira de veludo e medido por polegadas. 
A senhora à direita da ilustração também teve seu vestido e seu penteado descritos no periódico francês e traduzidos para o brasileiro. Enquanto no texto em francês o penteado é detalhado por estar amarrado atrás e preso por um pente com brilhantes, na tradução em português o cabelo é descrito como um "penteado de bandos ondeados simulando canudos transversais, [com] um pente marchetado de prata, guarnecido de pérolas por cima" (0 JORNAL DAS SENHORAS, n. 31, 1 ago. 1852, p. 3).

Da mesma forma que o penteado, o vestido é descrito com certa diferença entre a versão original e sua tradução. Na versão em francês, o modelo é detalhado com uma capa de renda formando a parte de trás, enquanto que, em português, a mesma capa é relatada como uma "finíssima camisinha aberta adiante" (O JORNAL DAS SENHORAS, n. 31, 1 ago. 1852, p. 3).

Entre a versão original e a tradução, $\mathrm{o}$ ato editorial era utilizado pelas redatoras a fim de adaptar o texto à realidade local, tendo em vista que muitas brasileiras não estavam acostumadas com a leitura exclusiva de periódicos sobre moda, como acontecia na França - o texto denso da descrição das estampas devia ser enxuto, facilitando a compreensão do público.

A falta de costume de ler tais jornais não significava que as mulheres não soubessem a arte de bordar e costurar. Afinal, muitas escolas para meninas tinham como parte de suas disciplinas esses conhecimentos. Conforme afirma Diana Crane, independentemente do ato de ver e ler o texto e as imagens sobre a moda,

donas de um abalizado conhecimento de costura, fizessem ou não suas próprias roupas, as mulheres, em sua grande maioria, examinavam esses figurinos tendo em vista a reprodução das roupas, ou a possibilidade de mandar fazê-las. (CRANE, 2006, p. 396)

A leitura também estava atrelada ao conhecimento das modistas, dos alfaiates e demais comerciantes. Esses profissionais procuravam estar constantemente atualizados sobre as vestimentas que circulavam pela Europa e pela imprensa da moda. Assim, a leitora que queria adquirir a mesma vestimenta ilustrada precisava das informações traduzidas para o português, além de levar o desenho para a modista, a fim de que ela tirasse as medidas e fizesse o vestido conforme o gosto da cliente.

As descrições das estampas traduzidas em 0 Jornal das Senhoras seguiam algumas características. Enquanto a versão original em francês era detalhada, sua tradução para o português contemplava apenas os elementos necessários ao conhecimento de suas leitoras. 0 encurtamento textual buscava facilitar a leitura das assinantes, bem como ajustar seu tamanho ao espaço do periódico.

0 fator que diferenciava uma imagem de outra eram os modelos de vestidos usados em ocasiões distintas. Enquanto as senhoras ilustradas nas figuras 1 e 2 utilizavam trajes de baile, as das figuras 3 e 4 foram representadas com vestidos para receber visitas pela manhã ou visitar alguém em dia de chuva. 


\section{FIGURAS 3 E 4 - VESTIDO PARA RECEBER VISTAS O PARA UM PASSEIO EM DIA CHUVOSO}
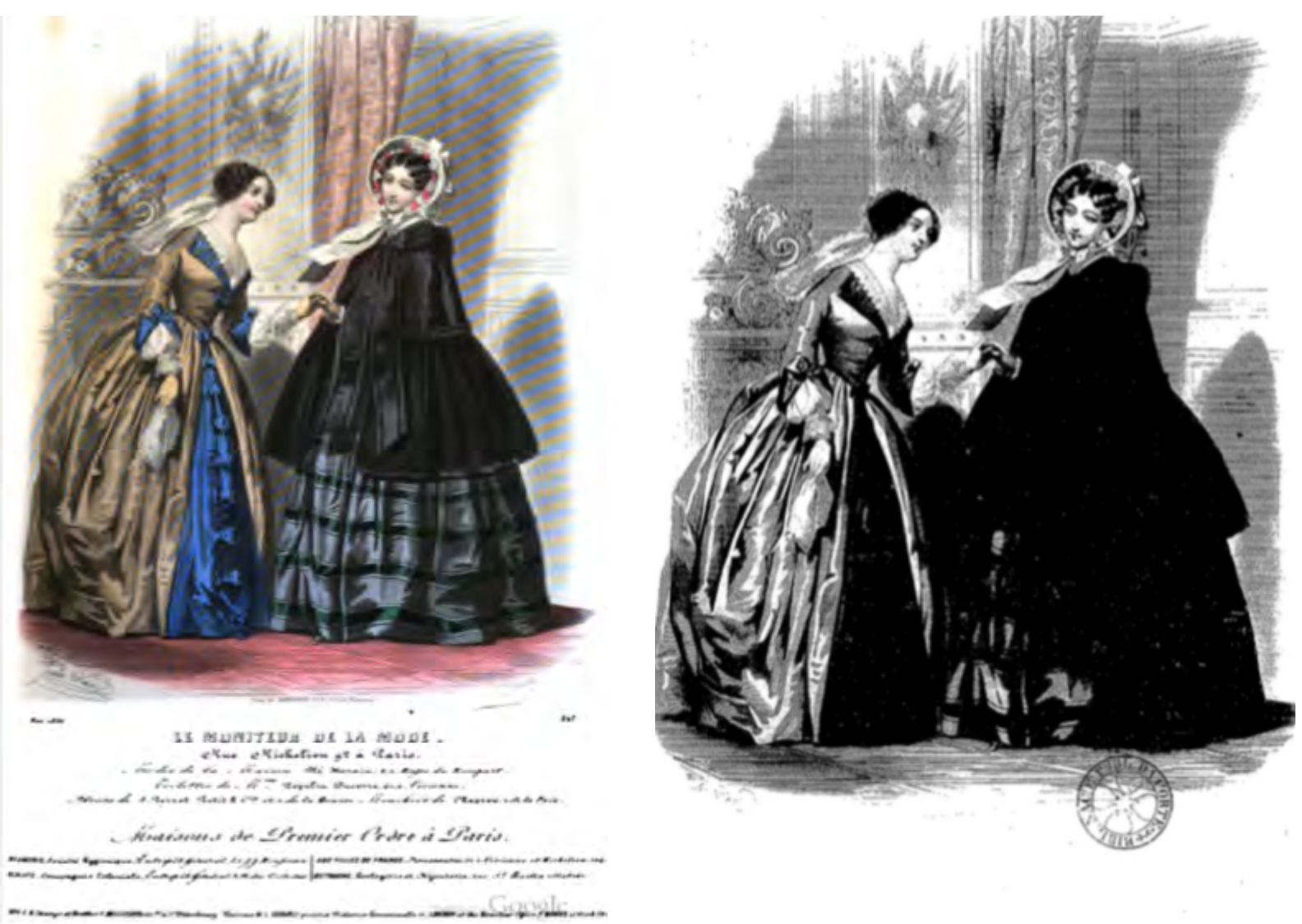

FONTE: Moniteur de la Mode. Paris: Imprimerie de E. Martinet, n. 6, jun. 1852, p. 97. Imagem obtida mediante impressão de tela do documento (figura 3). O Jornal das Senhoras. Rio de Janeiro: Tipografia do Jornal das Senhoras, n. 33, 15 ago. 1852, p. 5. Imagem obtida mediante impressão de tela do documento (figura 4).

A dama ilustrada à esquerda nas figuras 3 e 4 usa um vestido liso sem guarnições nas saias ou estampas floridas, características de eventos festivos. Já a senhora à direita é representada com um chapéu para proteção do sol e da chuva, bem como com uma capa e um capuz.

As distintas estampas da moda parisiense anexadas em 0 Jornal das Senhoras traduziam o misto de vestimentas usadas em diferentes espaços de sociabilidade. Sua circulação levava poucos meses, o que causava a sensação de novidade e atualidade sobre os trajes usados do outro lado do Atlântico.

Mais do que essa percepção, ter acesso aos periódicos sobre moda e trajar as vestimentas descritas neles denotava conhecimento, bom gosto, elegância, conferindo prestígio e distinção social. Conhecer esses dispositivos normativos indicava socialmente quem fazia, ou não, parte da rede de sociabilidade pautada pelos padrões do bom-tom na moda. Nesse sentido, era melhor ser surpreendida com uma apresentação ruim do que ser flagrada malvestida. 


\section{Considerações finais}

Para além das frivolidades, o universo da moda deflagrou um processo de transferência e de mediação cultural envolvendo diversos agentes históricos. Com finalidades específicas, esses indivíduos contribuíram para propagar a moda francesa no Brasil e para torná-la referencial de elegância, prestígio e distinção social.

0 ato de ver as estampas e ler suas respectivas descrições era essencial para vestir o que estava na moda, sair do espaço privado e frequentar o público. Nesse processo, as redatoras-chefes do 0 Jornal das Senhoras desempenharam papel significativo ao realizarem o ato editorial na descrição das imagens, moldando uma pedagogia do olhar. Permeado por gostos e escolhas, esse dispositivo de saber determinava o que era considerado de bom-tom e elegante, estando ambos vinculados ao ideal de progresso e modernidade.

Tantas diferenças nos tipos de vestimentas, adereços, penteados e cores indicavam a complexidade existente no universo da moda, bem como uma linguagem específica a qual as mulheres deveriam conhecer, a fim de permanecerem ligadas às diferentes redes de solidariedade e sociabilidade por onde circulavam.

Se para essas mulheres era permitido participar de determinados divertimentos mesmo que elas desconhecessem seu conteúdo, como relatado no caso da Folia de Reis ou na apresentação dos cantores franceses malvestidos, entretanto não lhes era conveniente acessar o espaço público ou receber uma visita no espaço doméstico sem estarem bem vestidas e bem arrumadas.

Portanto, o provérbio popular "o que os olhos não veem o coração não sente" fazia sentido àquilo que dizia respeito às apresentações, aos eventos e aos divertimentos sociais desconhecidos pelo público, porém, para frequentá-los era necessário ver, ler e escolher aquilo que seria vestido em cada ocasião, pois quando se tratava de moda, "o que os olhos não veem o corpo não veste".

\section{Referências}

BARBOSA, Everton Vieira. Páginas de sociabilidade feminina: sensibilidade musical no Rio de Janeiro Oitocentista. São Paulo: Editora Alameda, 2018.

BARTHES, Roland. Sistema da moda. Trad. Lineide do Lago Salvador Mosca. Revisão e supervisão de Isaac Nicolau Salum. São Paulo: Companhia Editora Nacional/ Editora da Universidade de São Paulo, 1979.

BOTREL, Jean-François. Impressos sem fronteiras no século XIX (França/Espanha/América Latina). In: GUIMARÃES, Valéria (org.). Transferências culturais: o exemplo da imprensa na França e no Brasil. Campinas: Mercado de Letras; São Paulo: Edusp, 2012, p. 55-72.

BRITO, Francisco de Paula. Correio das Modas. Rio de Janeiro: Tipografia de Eduardo e Henrique Laemmert, 1839-1840. Disponível em: http://memoria.bn.br/DocReader/ docreader.aspx?bib=717274\&pasta=ano\%20183\&pesq=. Acesso em: 10 jan. 2019. 
BRITO, Francisco de Paula. Marmotana Corte. Rio de Janeiro: Tipografia de Paula Brito, 1849-1852. Disponível em: http://memoria.bn.br/DocReader/docreader.aspx?bib=706906\&pasta=ano\%20 184\&pesq=. Acesso em: 10 jan. 2019.

CARELI, Mario. Cultures croisées: histoire des échanges culturels entre la France et le Brésil de la découverte aux temps modernes. Préface de Gilbert Durant. Paris: Nathan, 1993 (Essais \& Recherches).

CARNEIRO, José Alcibíades. 0 mentor das brasileiras. São João del Rey: Typographia do Astro, 1829-1832. Disponível em: http://memoria.bn.br/DocReader/docreader.aspx?bib= 778672\&pasta=ano\%20182\&pesq=. Acesso em: 10 jan. 2019.

CRANE, Diana. A moda e seu papel social: classe, gênero e identidade das roupas. Trad. Cristiana Coimbra. São Paulo: Editora Senac São Paulo, 2006.

DONEGÁ, Ana Laura. A revista Novo Correio de Modas (1852-1854): moda e literatura francesa com toque tropical. RITA [En ligne], n. 7: juin 2014, mis en ligne le 26 juin 2014. Disponível em: http://www.revue-rita.com/traitsdunion7/a-revista-novo-correio-de-modas-1852-1854moda-e-literatura-francesa-com-toque-tropical.html. Acesso em: 10 jan. 2019.

GOUBAUD, Camille Adouphe. Le Moniteur de la Mode. Paris: Imprimerie de E. Martinet, 1843-1913.

GUIMARÃES, Valéria. Les journaux français publiés au Brésil et les échanges transnationaux (1854-1924). Médias 19 [En ligne], La presse francophone du Brésil, Publications, Le journalisme francophone des Amériques au XIXe siècle, mis à jour le 7 mars 2018. Disponível em: http://www.medias19.org/index.php?id=23789. Acesso em: 10 jan. 2019.

GUIMARÃES, Valéria. Revistas francesas no Brasil. Caminhos da modernidade: catálogos e mediadores (Rio de Janeiro e São Paulo, séculos XIX e XX). Territórios e fronteiras (online), v. 9, 2016, p. 16-42. Disponível em: http://www.ppghis.com/territorios\&fronteiras/index. php/v03n02/article/view/574/pdf_1. Acesso em: 10 jan. 2019.

HAHN, H. Hazel. Scenes of parisian modernity: culture and consumption in the nineteenth century. New York: Palgrave Macmillan, 2009.

HILSDORF, Maria Lucia Spedo. História da educação brasileira: leitura. São Paulo: Pioneira Thomson Learning, 2005.

LUCA, Tania Regina de. A Ilustração (1884-1892): circulação de textos e imagens entre Paris, Lisboa e Rio de Janeiro. São Paulo: Editora Unesp, 2018.

LUCA, Tania Regina de. AIlustração (1884-1892) e a circulação internacional de imagens. In: SEMINÁRIO INTERNACIONAL: A IMPRENSA DA BELLE ÉPOQUE. Rio de Janeiro: Casa Rui Barbosa, 15 ago. 2017. Disponível em: https://www.youtube.com/watch?v=4bFayaey3kU. Acesso em: 10 jan. 2019. 
MENEZES, Lená Medeiros de. Francesas no Rio de Janeiro: modernização e trabalho segundo o Almanak 'Laemmert' (1844-1861). Revista do IHGB, ano 165, n. 423, p. 11-31, abr./jun. 2004.

MILLET, Audrey Patrizia. Histoire de la mode: de l'antiquité à nos jours. Paris: Belin, 2020.

MONTELEONE, Joana. 0 circuito das roupas: a Corte, o consumo e a moda (Rio de Janeiro, 1840-1889). 2013. 352 páginas. Tese (Doutorado em História Econômica) Universidade de São Paulo, São Paulo, 2013. Disponível em: http://www.teses.usp.br/teses/ disponiveis/8/8137/tde-11042014-112626/pt-br.php. Acesso em: 10 jan. 2019.

NORONHA, Joanna Paula Manso de; VELlASCO, Violante Atabalipa Ximenes de Bivar e; NEVES, Gervasia Nunezia Pires dos Santos. O Jornal das Senhoras. Rio de Janeiro: Typographia Parisiense, 1852-1855. Disponível em: http://memoria.bn.br/DocReader/ docreader.aspx?bib=700096\&pasta=ano\%20185\&pesq=. Acesso em: 10 jan. 2019.

OUVRY-VIAL, Brigitte. L'acte éditorial: vers une théorie du geste. Communication \& langages, n. 154, décembre 2007, p. 59-74. Disponível em: https://www.researchgate.net/ publication/250375667_L'acte_editorial_vers_une_theorie_du_geste. Acesso em: 10 jan. 2019.

PALMEIRAS, Julio Floro das. O Espelho Diamantino. Rio de Janeiro: Typographia de Pierre Palcher-Seignot, 1827-1828. Disponível em: http://memoria.bn.br/DocReader/docreader. aspx?bib=700312\&pasta=ano\%20182\&pesq=. Acesso em: 10 jan. 2019.

RAINHO, Maria do Carmo Teixeira. A cidade e a moda. 1. ed. Brasília: Ed. UnB, 2002.

SILVA, Ana Claudia Suriani da. A gênese da revista e da crônica de moda brasileiras (18271851). Miscelânea, Assis, v. 24, jul. /dez. 2018, p. 45-64. Disponível em: http://seer.assis. unesp.br/index.php/miscelanea/article/view/1217/ 1127. Acesso em: 15 maio 2020.

SILVA, Ana Claudia Suriani da. Moda, transferências culturais e história do livro. dObra[s], v. 10, n. 22, 2017, p. 177-201. Disponível em: https://dobras.emnuvens.com.br/dobras/ article/view/642. Acesso em: 10 jan. 2019.

SOUSA, Francisco Eleuterio de. O Espelho. Rio de Janeiro: Typographia de Paula Brito, 1859-1860. Disponívelem:http://memoria.bn.br/DocReader/docreader.aspx?bib=700037\&pasta=ano\%20 185\&pesq=. Acesso em: 10 jan. 2019.

\section{Agradecimentos}

Eu agradeço ao Conselho de Aperfeiçoamento de Pessoal de Nível Superior (CAPES). 